\title{
Synthesis and Characterization of Metal Complexes of Schiff's Base Ligands Derived from 4-Carboxy Hydrazide-5, 6-Diphenyl-3[2-H]Pyridazone
}

\author{
Faten Z. Mahmoud ${ }^{1, ~ *, ~ A t e f ~ A . ~ T . ~ R a m a d a n ², ~ M o h a m e d ~ M . ~ M a h m o u d ~}{ }^{2}$, Fouz M. Omar ${ }^{2}$ \\ ${ }^{1}$ Chemistry department, University College for Girls, Ain Shams University, Cairo, Egypt \\ ${ }^{2}$ Chemistry department, Faculty of Education, Ain Shams University, Cairo, Egypt
}

Email address:

faten_zm@yahoo.com (F.Z.Mahmoud)

\section{To cite this article:}

Faten Z. Mahmoud, Atef A. T. Ramadan, Mohamed M. Mahmoud, Fouz M. Omar. Synthesis and Characterization of Metal Complexes of Schiff's Base Ligands Derived from 4-Carboxy Hydrazide-5, 6-Diphenyl-3[2-H]Pyridazone. Modern Chemistry. Special Issue: Synthesis and Microbial Screening of Coordination and Organic Compounds. Vol. 3, No. 1-1, 2015, pp. 15-26. doi: 10.11648/j.mc.s.2015030101.13

\begin{abstract}
A new ligand, 4-[carboxy- $\alpha$-(2-hydroxyphenyl) ethylidene hydrazide-5,6-diphenyl-3(2H) pyridazinone (CHDP), were synthesized and characterized by ${ }^{1} \mathrm{H}-\mathrm{NMR}$, IR spectra and elemental analysis. The dissociation equilibrium constant of CHEDP as well as the equilibrium constant for different $\mathrm{M}^{+\mathrm{n}}$-CHEDP complexes were reported at different temperatures in $75 \%$ (v/v) dioxane-water media and constant ionic strength. The stability constants of CHDP complexes with transition and nontransition ions were evaluated. The thermodynamic parameters were also calculated and discussed. A series of mono nuclear protic $\mathrm{M}(\mathrm{HL}), \mathrm{M}(\mathrm{HL})_{2}, \mathrm{ML}(\mathrm{HL})$ and non-protic $\mathrm{ML}_{2}$ complex species were formed in solutions. The structure of the solid complexes formed between CHEDP and cobalt (II), copper (II) and iron (III) are substantiated by elemental analysis, mass spectra, thermal studies (TG and DSC) and IR spectra.
\end{abstract}

Keywords: CHEDP Ligand, Potentiometric Titration, Spectrophotometric Studies of Fe (III)- CHEDP Complexes, Solid Complexes

\section{Introduction}

Pyridazines are compounds act as complexing agents, 2hydrazino pyridazine and their metal complexes have many analytical application and also of a great interest in various biological systems $[1,2]$.

The synthesis of pyridazine hydrazines may lead to prepare several interesting chelating agents [3:5]. The condensation reaction takes place between hydrazine group and carbonyl group to give ligand with chromophoric group (1). These classes of compound are structurally related to the corresponding azo-pyrazolone dyes (II) and different only on the position of azo- or hydrazo- group relative to the nitrogenous nucleus $[6,7]$.

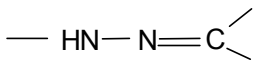

(I)

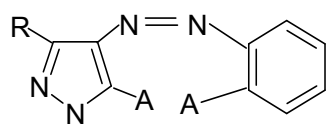

(II)
In the present communication, the metal complexes formed with 4-[carboxy-2-hydroxybenzylidene]-5,6diphenyl-3-(2H)-pyridazinone (CHDP) and 4-[carboxy- $\alpha-(2-$ hydroxyphenyl) ethylidene hydrazine-5,6-diphenyl-3(2H) pyridazinone (CHEDP) are discussed.

\section{Experimental}

\subsection{Materials}

All chemicals were commercial product of analytical grade. Solvents were purified by conventional methods. The parent compound 4-carboxy hydrazide-5,6-diphenyl-3-(2H) pyridazinone was synthesized as previously described [8].

\subsection{Preparation of Ligands}

CHEDP and CHDP were obtained by mixing $100 \mathrm{ml}$ of ethanolic solution of 0.01 mole of 4-carboxy hydrazide-5,6diphenyl-3-(2H) pyridazinone and 0.012 moland e of ohydroxy acetophenone and o-hydroxy salicylaldehyde, respectively. The reaction mixture was refluxed for three 
hours. Then the formed solid was crystallized from ethanol to

\subsection{Synthesis of the Complexes} give CHEDP, m. p. $255,167^{\circ} \mathrm{C}$, respectively.

Table (1). Analytical data and general behavior of CHDP complexes.

\begin{tabular}{|c|c|c|c|c|c|c|c|}
\hline \multirow{2}{*}{ Compound } & \multirow{2}{*}{ Colour } & \multicolumn{4}{|c|}{ Found (Calc.) } & \multirow{2}{*}{$\mu_{\text {eff. }}$ (B.M.) } & \multirow{2}{*}{$\begin{array}{l}\text { Conductance } \\
(\mu \mathrm{S} / \mathrm{cm})\end{array}$} \\
\hline & & $\mathrm{C}$ & $\mathbf{H}$ & $\mathbf{N}$ & M & & \\
\hline CHDP & & $\begin{array}{l}67.60 \\
(67.29)\end{array}$ & $\begin{array}{l}4.60 \\
(4.67)\end{array}$ & $\begin{array}{l}13.16 \\
(13.08)\end{array}$ & & & \\
\hline CHEDP & & $\begin{array}{l}67.50 \\
(67.87)\end{array}$ & $\begin{array}{l}4.80 \\
(4.78)\end{array}$ & $\begin{array}{l}12.55 \\
(12.67)\end{array}$ & & & \\
\hline $\begin{array}{l}{\left[\mathrm{Cu}\left(\mathrm{C}_{24} \mathrm{H}_{17} \mathrm{~N}_{4} \mathrm{O}_{3}\right)\left(\mathrm{H}_{2} \mathrm{O}\right)_{3}\left(\mathrm{NO}_{3}\right] \cdot \mathrm{H}_{2} \mathrm{O}\right.} \\
{ }^{*} \mathrm{M} . \mathrm{W} .=606.55 \\
*_{*} 601\end{array}$ & Green & $\begin{array}{l}47.71 \\
(47.49)\end{array}$ & $\begin{array}{l}4.22 \\
(4.12)\end{array}$ & $\begin{array}{l}11.35 \\
(11.54)\end{array}$ & $\begin{array}{l}10.50 \\
(10.48)\end{array}$ & 1.82 & 15 \\
\hline $\begin{array}{l}{\left[\mathrm{Co}\left(\mathrm{C}_{24} \mathrm{H}_{17} \mathrm{~N}_{4} \mathrm{O}_{3}\right)\left(\mathrm{H}_{2} \mathrm{O}\right)_{3}\right] \mathrm{NO}_{3} \cdot \mathrm{H}_{2} \mathrm{O}} \\
\text { *M. W. } 601.90 \\
{ }^{* *} 602\end{array}$ & Orange & $\begin{array}{l}48.20 \\
(47.93)\end{array}$ & $\begin{array}{l}4.00 \\
(3.94)\end{array}$ & $\begin{array}{l}11.54 \\
(11.65)\end{array}$ & $\begin{array}{l}9.92 \\
(9.80)\end{array}$ & 4.48 & 67 \\
\hline $\begin{array}{l}{\left[\mathrm{Fe}\left(\mathrm{C}_{24} \mathrm{H}_{16} \mathrm{~N}_{4} \mathrm{O}_{3}\right)\left(\mathrm{H}_{2} \mathrm{O}\right)_{3}\right] 2 \mathrm{H}_{2} \mathrm{O} . \mathrm{NO}_{3}} \\
{ }^{*} \mathrm{M} \text {. W. } 615.85 \\
{ }^{* *} 603\end{array}$ & Black & $\begin{array}{l}46.98 \\
(46.84)\end{array}$ & $\begin{array}{l}4.19 \\
(4.07)\end{array}$ & $\begin{array}{l}11.33 \\
(11.38)\end{array}$ & $\begin{array}{l}9.00 \\
(9.08)\end{array}$ & 5.67 & 75.2 \\
\hline
\end{tabular}

*molecular weight

** molecular weight (mass spectra data)

Copper (II), $\mathrm{Co}(\mathrm{II})$ and $\mathrm{Fe}$ (III) chelating were prepared by adding ethanolic solution of CHDP ligand $(\approx 0.01$ moles $)$ to aqueous solution of metal nitrate $(0.01$ moles). The mixture was refluxed for one hour. The solid obtained has filtered off, washed and dried, the elemental analysis of the complexes are given in Table 1. Also, the complexes were analyzed for their metal content by EDTA titrations using suitable indicator.

\subsection{Measurements}

Potentiometric studies were done with WTW digital pHmeter with a combined glass electrode. Solutions were adjusted to $0.10 \mathrm{M}$ ionic strength by addition of $\mathrm{KNO}_{3}$ and maintained at constant temperature $\left( \pm 0.05^{\circ} \mathrm{C}\right)$ with constant temperature water circulated through a sealed of jacketed cell. The ligand solution in $75 \%(\mathrm{v} / \mathrm{v})$ dioxane-water reached with standard carbonate-free $\mathrm{KOH}$ in $75 \%(\mathrm{v} / \mathrm{v})$ dioxane-water and the $\mathrm{pH}$ had recorded after addition of each increment of base. Metal-chelate formation equilibriums were measured with $3: 1$ molar ratios of the ligand to metal ion $(0.001 \mathrm{M})$. The correction of $\mathrm{pH}$ value in $75 \%(\mathrm{v} / \mathrm{v})$ dioxane-water was taken as $+0.28[9]$.

Infrared spectra ( $\mathrm{KBr}$ discs) were recorded on a PerkinElmer 437 spectrometer $\left(4000-400 \mathrm{~cm}^{-1}\right)$. The electronic spectra were measured at $25^{\circ} \mathrm{C}$ with Jasco V-550 UV-visible spectrometer, with $1 \mathrm{~cm}$ matched quartz cells. ${ }^{1} \mathrm{H}-\mathrm{NMR}$ spectra were recorded on Varian EM-390, 90 MHZ. NMRspectrometer with TMS as an internal standard.

Conductance of $1 \times 10^{-3} \mathrm{M}$ solution of the solid complex in DMF was measured using WTW D-812 Weil heium conductivity meter model LBR, fitted with cell model LTA 100.

Magnetic moments were measured by the Gouy method at room temperature using Johnson Matthey A/80 Product, model no. M KI, magnetic susceptibility balance with $\mathrm{Hg}$ $\left[\mathrm{Co}(\mathrm{CNS})_{4}\right]$ as celibrant. Diamagnetic correction was calculated from Pascal's constants. The effective magnetic moment $\mathrm{M}_{\text {eff }}$ was determined according to: $M_{\text {eff }}=2.828\left(X_{M}^{\text {corr }} . T\right)^{1 / 2}$, where $X_{M}$ being the corrected molar magnetic susceptibility in e. $\mathrm{m}$. $\mathrm{u}, \mathrm{mol}^{-1}$ and $\mathrm{T}$ in $\mathrm{K}$.

Thermal analysis (TG-DSC) was carried out on Shim adzu-5O thermal analyzer at heating rate $10^{\circ} \mathrm{C} / \mathrm{min}$ in nitrogen atmosphere using TA-SO WSI program. Mass spectra were recorded on a Hewlett-Packard mass spectrometer; model MS 5988, electron energy $70 \mathrm{eV}$.

\section{Results}

\subsection{Ligand Protonation Constant}

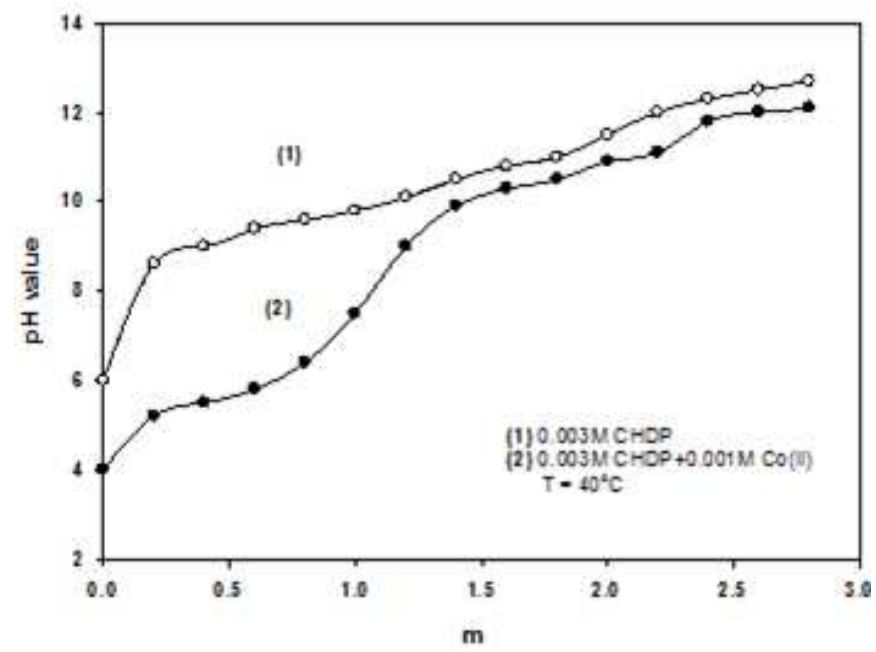

Fig. 1. Potentiometric equilibrium curves for CHDP in absence and presence of $\mathrm{Co}(I I)$

The protonation constants $\left(p K_{n}^{H}, n=1,2,3, \ldots\right)$ of the ligand CHDP and CHEDP are determined by direct poteniometric measurements. A representative titration curves for CHDP in the absence and presence of some metal ion is plotted in Fig. 1. No conclusion about the protic nature 
or the stepwise dissociation of $\mathrm{OH}$ and $\mathrm{NH}$ protons could be drowned from the titration curves of the free ligands. The protic nature of the ligands is substantiated from the metalligand titration curves, only two protons were liberated as indicated by the inflection point at $\mathrm{m}=2$ ( $\mathrm{m}$ is the number of moles of base added per mole of metal). This indicates that under these conditions the ligand behaves as a diprotic species. For general protonation equilibrium:

$$
H^{+}+H_{n-1} L \Leftrightarrow H_{n} L \quad(\mathrm{n}=1 \text { or } 2)
$$

The constants $\left(K_{n}^{H}\right)$ were determined from hydrogen ion concentration of the ligand solution for each increment of the base added. The absence of any inflection point in the titration curves of the free ligand indicates that the protonation constants of $-\mathrm{OH}$ and $-\mathrm{NH}$ groups are close to each other (less than 2.8). The values of $K_{1}^{H}(-\mathrm{OH})$ and $K_{2}^{H}(-$ $\mathrm{NH})$ are calculated from potentiometric data [10]. Since, the value of the ionic product of water in $75 \%(\mathrm{v} / \mathrm{v})$ dioxanewater medium is 18.7 [11], both hydrogen and hydroxide ions concentration are negligible in the dissociation region.

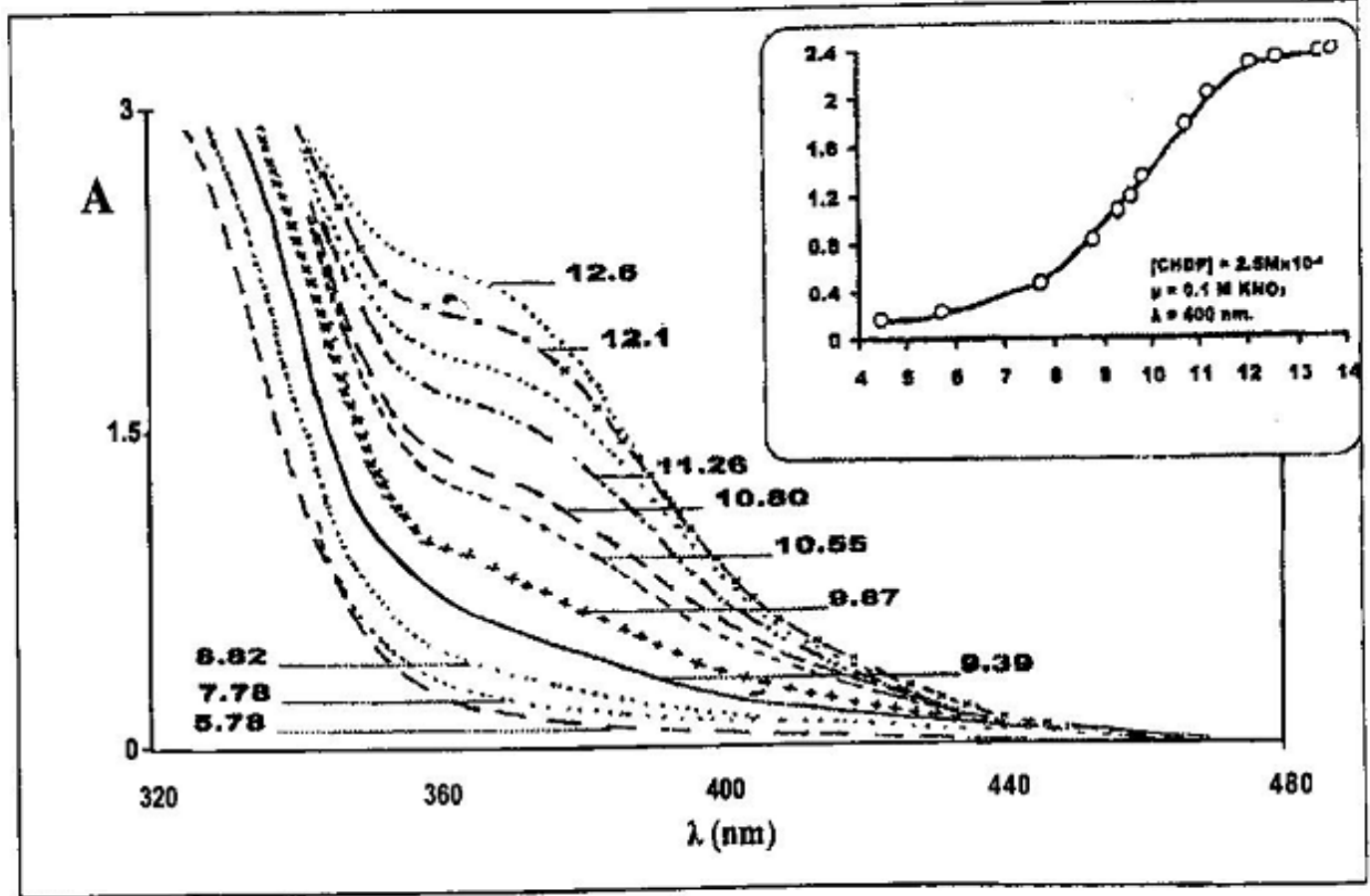

Fig. 2. Electronic spectra of $C H D P$ at different $p H$ values

In addition to $\mathrm{pH}$-metric method, spectrophotometric method is further assessed for the calculation of protonation constants. The electronic absorption spectra of CHDP in $75 \%$ (v/v) dioxane-water display three absorption bands at 321, 275 and $220 \mathrm{~nm}$ and having molar absorptivities $2.00 \times 10^{4}$, $3.75 \times 10^{4}$ and $1.30 \times 10^{5} \mathrm{~mol}^{-1} \cdot \mathrm{cm}^{-1}$ respectively, like those reported for pyridazine ring at 245 and $295 \mathrm{~nm}$ [10]. The two bands at 275 and $321 \mathrm{~nm}$ in CHDP spectra are attributed to enhanced $\pi \rightarrow \pi^{*}$ transition (K-band) over the whole conjugation system and an enhanced $n \rightarrow \pi^{*}$ transition (Rband) respectively. At fixed lignd concentration, the absorbance was found to be $\mathrm{pH}$-dependent Fig. 2. The results were analyzed for the calculation of the protonation constants of CHDP in $75 \%(\mathrm{v} / \mathrm{v})$ dioxane-water using the following equation [10].

$$
\frac{\left[H^{+}\right]}{K_{1}^{H}} x \frac{\left(\varepsilon-\varepsilon_{C}\right)}{\left(\varepsilon-\varepsilon_{A}\right)}+K_{2}^{H}=-\left[H^{+}\right] x \frac{\left(\varepsilon-\varepsilon_{M}\right)}{\left(\varepsilon-\varepsilon_{A}\right)}
$$

where, $\varepsilon_{C}, \varepsilon_{A}$ and $\varepsilon_{M}$ are the molar absorptivities (extinction coefficient) for the analytical wavelength at given $\mathrm{pH}$ for di-protonated, mono-protonated and non-protonated species respectively.

The plot of $\left[H^{+}\right] \frac{\left(\varepsilon-\varepsilon_{M}\right)}{\left(\varepsilon-\varepsilon_{A}\right)}$ versus $\left[H^{+}\right] \frac{\left(\varepsilon-\varepsilon_{C}\right)}{\left(\varepsilon-\varepsilon_{A}\right)}$ gives straight line of slope equals to $\left(-1 / K_{1}^{H}\right)$ and intercept equal $\left(K_{2}^{H}\right)$. The values of $K_{1}^{H}$ and $K_{2}^{H}$ are refined using least square method. The obtained values are found to be 9.70 and 10.87 for $K_{1}^{H}$ and $K_{2}^{H}$ respectively compared to 9.71 and 10.82 obtained potentiometrically.

\subsection{Ligand-Metal Ion Interactions}

The protonation equilibrium curve for Co-CHDP at $40^{\circ} \mathrm{C}$ is shown in Fig. 1. The shapes of these curves clearly indicate the formation of simple mononuclear chelate as well as various protonated species. The complex equilibrium in the first buffer region may be represented by:

$$
\begin{gathered}
M^{z+}+H_{2} L \Leftrightarrow M(H L)^{(z-1)+}+H^{+} \\
M(H L)^{(z-1)+}+H_{2} L \Leftrightarrow M(H L)_{2}^{(z-2)+}+H^{+}
\end{gathered}
$$

Further addition of base results the subsequent dissociation 
of two protons as indicated by the amount of base required per metal chelate. The reaction involved may be described by the equilibriums:

$$
\begin{gathered}
M(H L)_{2}^{(z-2)+} \Leftrightarrow M L(H L)^{(z-3)+}+H^{+} \text {and } \\
M L(H L)^{(z-3)+} \Leftrightarrow M L_{2}^{(z-4)+}+H^{+} \\
K_{M(H L)_{2}}^{H}=\frac{\left[M(H L)_{2}^{(z-2)+}\right]}{\left[M L(H L)^{(z-3)+}\right]\left[H^{+}\right]} \\
K_{M L(H L)}^{H}=\frac{\left[M L(H L)^{(z-3)+}\right]}{\left[M L_{2}^{(z-4)+}\right]\left[H^{+}\right]}
\end{gathered}
$$

Computer assisted algebraic method use to solve the overlapping complex protonation constants involved in the second buffer regions. Calculation of the constants $K_{M(H L)}^{M}$ and $K_{M(H L)_{2}}^{M}$ was carried out using standard procedures based on the calculation of the average number of the ligand bound per metal ion $\left(n_{H L}^{-}\right)$and the free ligand concentration $\left[H L^{-}\right]$using the first buffer region of the titration curve. Values of the constants are obtained from the intercept and slope of the linear relationship:

$$
\frac{n_{H L}^{-}}{\left(1-n_{H L}^{-}\right)[H L]}=\frac{\left(2-n_{H L}^{-}\right)}{\left(1-n_{H L}^{-}\right)} x K_{M(H L)_{2}}^{M}+K_{M(H L)}^{M}
$$

The best straight line is obtained by the method of least squares. In a similar way, the second buffer region in the titration curves is used to calculate the constants $K_{M L(H L)}^{M}$ and $K_{M L}^{M}$ as well as the constants $K_{M L(H L)}^{H}$ and $K_{M L_{2}}^{H}$. The values

\begin{tabular}{|c|c|c|c|c|c|c|c|c|}
\hline \multirow{2}{*}{ Ligand } & \multirow{2}{*}{$\begin{array}{l}\text { Symbol of proton } \\
\text { constant }\end{array}$} & \multicolumn{4}{|c|}{ Protonation constant } & $\Delta \mathbf{G}$ & $\Delta \mathbf{H}$ & \multirow{2}{*}{$\begin{array}{l}\Delta \mathrm{S} \\
\mathrm{Cal} / \mathrm{mole} . \mathrm{K}\end{array}$} \\
\hline & & $10^{\circ} \mathrm{C}$ & $20^{\circ} \mathrm{C}$ & $30^{\circ} \mathrm{C}$ & $40^{\circ} \mathrm{C}$ & Kcal/ 1 & & \\
\hline \multirow{2}{*}{ CHDP } & $p K_{1}^{H}$ & 10.72 & 10.37 & 10.17 & 09.71 & 14.11 & 13.76 & +1.2 \\
\hline & $p K_{2}^{H}$ & 12.18 & 11.82 & 11.63 & 10.82 & 16.11 & 19.12 & -9.9 \\
\hline \multirow{2}{*}{ CHEDP } & $p K_{1}^{H}$ & 11.09 & 10.76 & 10.11 & 09.95 & 14.03 & 16.51 & -8.2 \\
\hline & $p K_{2}^{H}$ & 12.45 & 12.14 & 11.93 & 11.17 & 16.55 & 16.26 & +1.0 \\
\hline
\end{tabular}
of stability constants as well as thermodynamic parameters were summarized in Tables 2, 3, 4, 5 and 6.

Table (2). Protonation constants and thermodynamic parameters of CHDP and CHEDP ligands at different temperatures $[75 \%(v / v)$ dioxane-water, $\mu=0.1 M$ $\left.\mathrm{KNO}_{3}\right]$

\begin{tabular}{|c|c|c|c|c|c|c|c|}
\hline Cation $\mathrm{M}^{2+}$ & $2^{\text {nd }}$ I. P. & $-\Delta G_{M(H L)}^{M}$ & $-\Delta G_{M(H L)_{2}}^{M}$ & $-\Delta G_{M L(H L)}^{M}$ & $-\Delta G_{M L_{2}}^{M}$ & $-\Delta G_{M(H L)_{2}}^{H}$ & $-\Delta G_{M L(H L)}^{H}$ \\
\hline $\mathrm{Cu}$ & 20.25 & 13.710 & 12.930 & 07.01 & 06.010 & 13.61 & 15.190 \\
\hline $\mathrm{Ni}$ & 18.18 & 10.650 & 09.350 & 07.39 & 06.240 & 13.33 & 14.250 \\
\hline $\mathrm{Co}$ & 17.03 & 09.750 & 07.750 & 07.41 & 06.160 & 13.61 & 15.190 \\
\hline $\mathrm{Zn}$ & 17.96 & 10.150 & 08.790 & 06.92 & 06.252 & 14.81 & 17.668 \\
\hline $\mathrm{Mn}$ & 15.65 & 07.580 & 06.540 & 06.20 & 05.420 & 14.52 & 16.630 \\
\hline $\mathrm{Cd}$ & 16.22 & 08.112 & 07.256 & 06.52 & 05.592 & 14.54 & 15.820 \\
\hline
\end{tabular}

Table (3). Equilibrium constants and thermodynamic parameters for the interaction of CHEDP with nickel (II) ions [75\% (v/v) dioxane-water, $\left.\mu=0.1 M \mathrm{KNO}_{3}\right]$

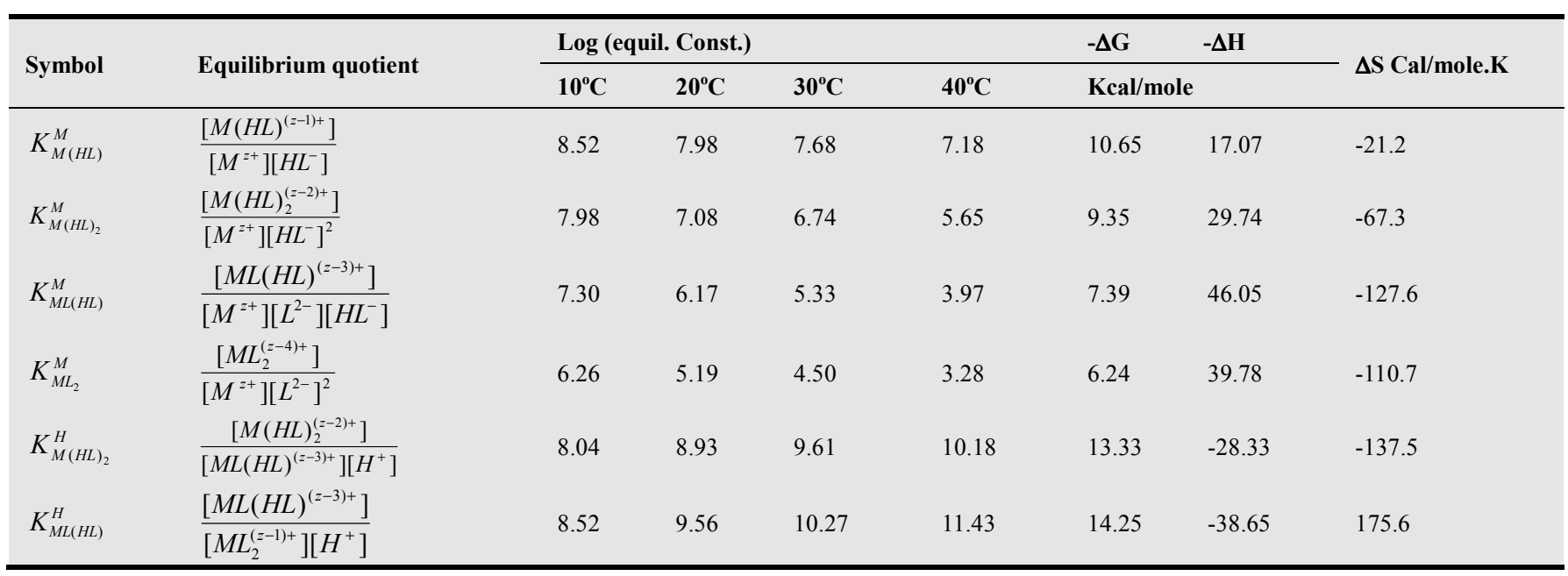

$\Delta \mathrm{G} \pm(0.08-0.22), \quad \Delta \mathrm{H} \pm(0.01-0.49), \quad \Delta \mathrm{S} \pm(0.1-1.0)$

Table (4). Relation between $2^{\text {nd }} I . P$. and free energies of formation constants for some transition metal-CHEDP chelates. 
Table (5). Relation between $2^{\text {nd }} I$. P. and enthalpy change of formation constants for some transition metal-CHEDP chelates.

\begin{tabular}{llllllll}
\hline Cation $\mathbf{M}^{2+}$ & $\mathbf{2}^{\text {nd }} \mathbf{I}$. P. & $-\Delta H_{M(H L)}^{M}$ & $-\Delta H_{M(H L)_{2}}^{M}$ & $-\Delta H_{M L(H L)}^{M}$ & $-\Delta H_{M L_{2}}^{M}$ & $-\Delta H_{M(H L)_{2}}^{H}$ & $-\Delta H_{M L(H L)}^{H}$ \\
\hline $\mathrm{Cu}$ & 20.25 & 18.570 & 43.930 & 42.200 & 38.760 & -20.590 & -20.530 \\
$\mathrm{Ni}$ & 18.18 & 17.070 & 29.740 & 46.050 & 39.780 & -28.330 & -38.650 \\
$\mathrm{Co}$ & 17.03 & 14.280 & 25.210 & 38.620 & 29.510 & -29.490 & -34.480 \\
$\mathrm{Zn}$ & 17.96 & 14.942 & 28.245 & 41.675 & 33.442 & 12.693 & -25.999 \\
$\mathrm{Mn}$ & 15.65 & 10.268 & 19.551 & 31.153 & 25.711 & 13.633 & -10.434 \\
$\mathrm{Cd}$ & 16.22 & 11.958 & 23.655 & 33.378 & 27.275 & 13.010 & 08.658 \\
\hline
\end{tabular}

Table (6). Entropy values for some transition metal-CHEDP complex systems

\begin{tabular}{|c|c|c|c|c|c|c|}
\hline Cation $\mathrm{M}^{2+}$ & $-\Delta S_{M(H L)}^{M}$ & $-\Delta S_{M(H L)_{2}}^{M}$ & $-\Delta S_{M L(H L)}^{M}$ & $-\Delta S_{M L_{2}}^{M}$ & $-\Delta S_{M(H L)_{2}}^{H}$ & $-\Delta S_{M L(H L)}^{H}$ \\
\hline $\mathrm{Cu}$ & 16.0 & 102.3 & 96.6 & 104.8 & -24.0 & -17.6 \\
\hline $\mathrm{Ni}$ & 6.4 & 67.3 & 121.1 & 106.9 & -49.5 & -80.5 \\
\hline Co & 4.5 & 57.6 & 101.8 & 72.9 & -52.4 & -63.7 \\
\hline $\mathrm{Zn}$ & 4.8 & 64.2 & 104.0 & 87.5 & 90.0 & -27.5 \\
\hline $\mathrm{Mn}$ & 2.7 & 42.9 & 77.8 & 64.4 & 92.9 & 20.5 \\
\hline $\mathrm{Cd}$ & 3.9 & 54.1 & 83.3 & 68.6 & 90.9 & 80.8 \\
\hline
\end{tabular}

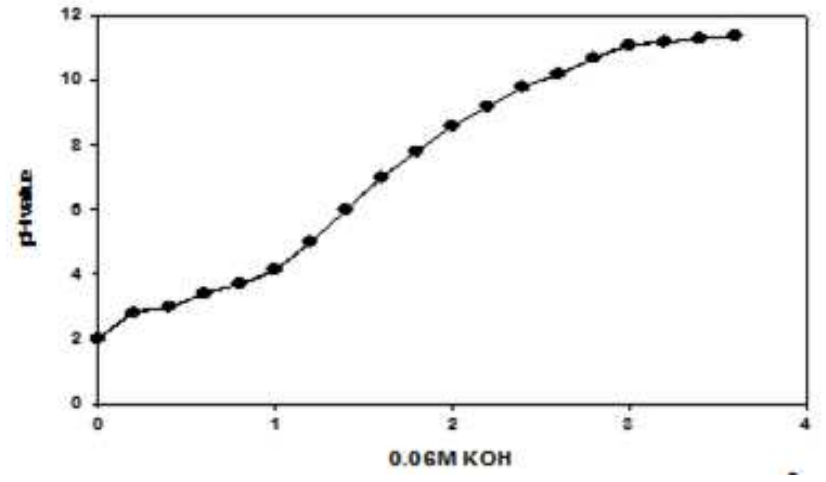

Fig. 3. Potentiometric equilibrium curve of 1:3 molar ratio of $\mathrm{Fe}^{+3}$ ion to CHDP in $75 \%(v / v)$ dioxane-water solvent

The poteniometric equilibrium curves of the Fe(III)-CHDP and Fe(III)-CHEDP systems show a curve similar to strong acid titration Fig. 3. The formation of iron chelate is so nearly complete even at low $\mathrm{pH}$, that the stability constant can not be accurately calculated from poteniometric data. For this reason, the values of stability constants for Fe(III)-CHDP and $\mathrm{Fe}$ (III)-CHEDP have been determined by spectrophotometric method.

On mixing a solution containing $\mathrm{Fe}(\mathrm{III})$ ions with the solution of CHDP in $75 \%(\mathrm{v} / \mathrm{v})$ dioxane-water, coloured complexes are formed. At constant metal ion concentration $\left[\mathrm{Fe}^{3+}\right]$ and varying ligand concentration, the absorbance increasing effectively at low concentrations of ligand but tends to attain a limiting value at higher concentrations Fig. 4 Multiple band spectra indicate the probable formation of complexes with varying stiochiometry. The intensities of peaks observed are function of both $\mathrm{pH}$ of the medium and the molar ratios of metal to ligand. As seen from Fig. 5, the absorbance increases rapidly with increase $\mathrm{pH}$ from 2 to 4 , followed by a plateau in $\mathrm{pH}$ region 4.0 - 9.0. From the absorbance-pH diagram, it can be concluded that the optimum $\mathrm{pH}$ values are $\approx 3.0$ for the formation of $\mathrm{Fe}$ (III)CHDP complex systems. In addition, it could be concluded that more than one species are formed. At $\mathrm{pH} 2.0$, the formation of protonated complexes $[\mathrm{Fe}(\mathrm{HL})]^{2+}$ and
$\left[\mathrm{Fe}(\mathrm{HL})_{2}\right]^{1+}$ are formed through the replacement of phenolic proton. On increasing the $\mathrm{pH}$ from 2.0 to 4.0 , the ionization of $\mathrm{NH}$ proton could take place and this leads to the formation of different species. These different absorbing species in the $\mathrm{pH}$ range from 2.0 to 9.0 is substantiated applying Coleman's graphical method [13]. Typical plots are given in Fig. 6 "a $\&$ b". The analysis revealed that only one absorbing species exists in the acidic region ( $\mathrm{pH}$ below 4.0), which probably formed between $\mathrm{Fe}(\mathrm{III})$ and acidic ligand Fig. 6a. Above $\mathrm{pH}$ 4.0 two absorbing species (protonated and non-protonated) are found as indicated by the linear plots shown in Fig. 6b. Above $\mathrm{pH}$ 6.0, the absorbance is nearly constant indicating that both the protonated $[\mathrm{ML}(\mathrm{HL})]$ and non-protonated $\left[\mathrm{ML}_{2}\right]$ are absorbing to the same extent $\left(\varepsilon_{M L(H L)} \approx \varepsilon_{M L}\right)$.

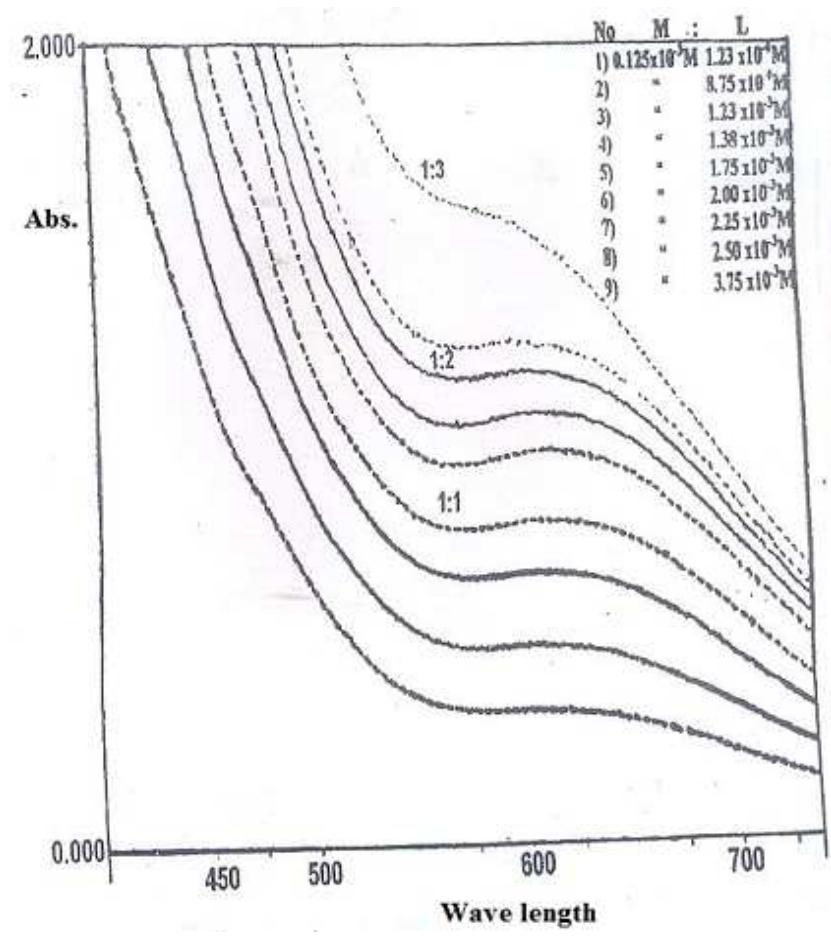

Fig. 4. Electronic spectra of $\mathrm{Fe}^{3+-} \mathrm{CHDP}$ complex in $75 \%(v / v)$ dioxanewater solvent 


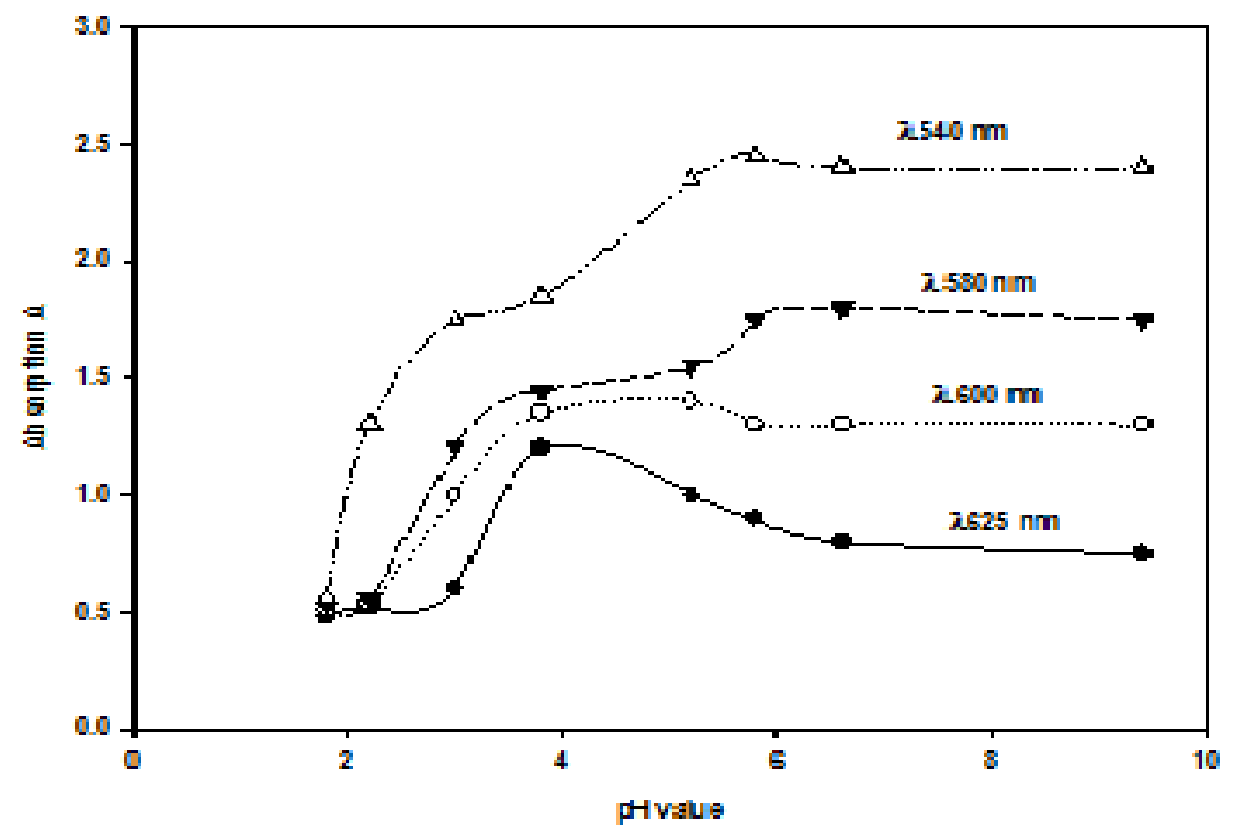

Fig. 5. Absorbance vs. pH plots for Fe(III)-CHDP Chelates

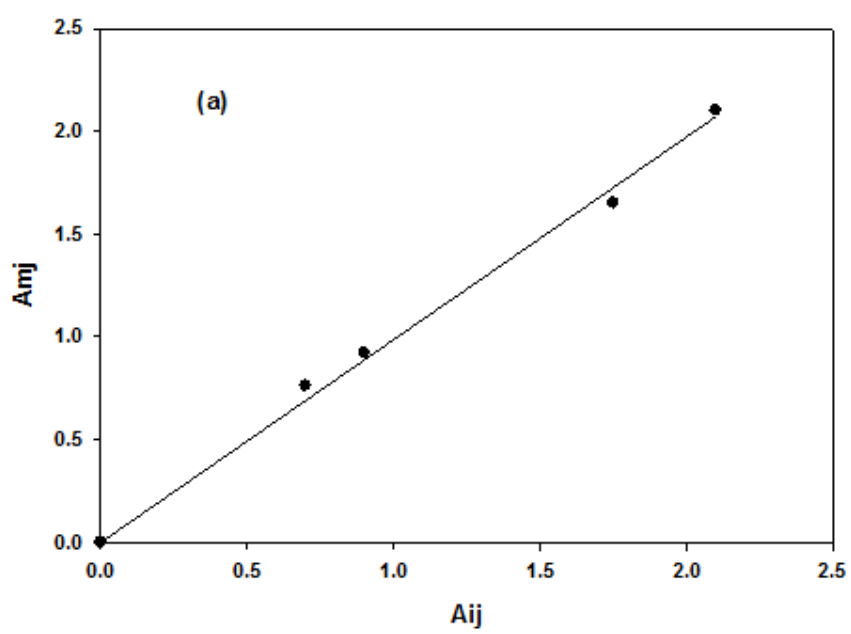

(a) $\mathrm{pH}$ : 0.4-3.77

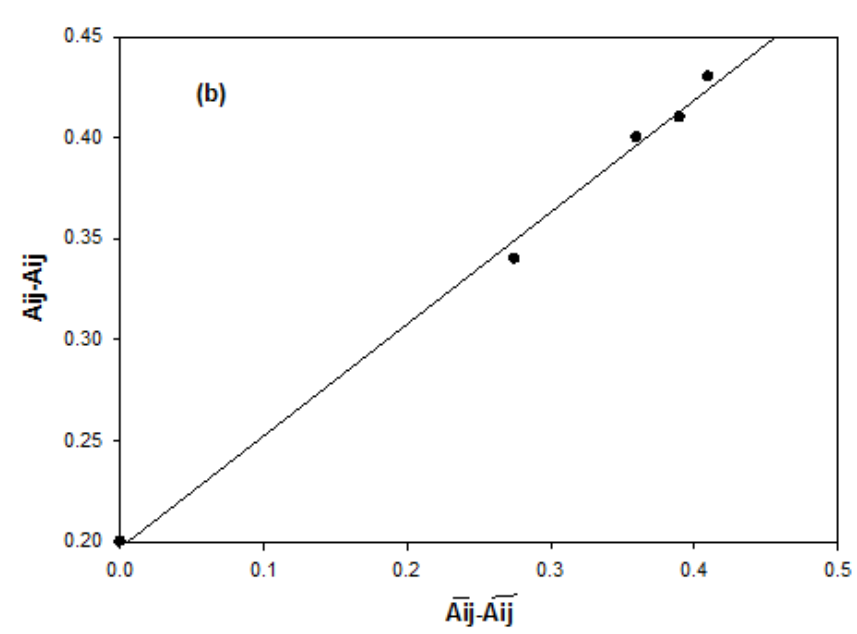

(b) $\mathrm{pH}: 4.00-9.00$

Fig. 6. Colman et. Al. plots for different Fe(III)-CHDP chelates

The composition of complexes formed in this study is determined using Job's and molar ratio methods [14]. All of these spectrophotometric methods indicate the formation of 1:1 and 1:2 (M:L) complexes. In molar ratio method, a sharp break in the line at 1:1 and 1:2 (M:L), indicating formation of 1:1 and 1:2 complex types. In Job's method the curve shows maximum absorbance at 0.5 mole fraction indicating the presence of 1:1 (M:L) complex type.

For studying the validity of Beer's law, a series of solutions containing constant excess concentration of ligand (CHDP or CHEDP) and variable concentration of Fe(III) ions all in 75\% $(\mathrm{v} / \mathrm{v})$ dioxane-water are prepared. The absorbance of these solutions is measured at fixed wavelength (usually $\lambda_{\max }$ ) the linear relation obtained between $C_{F^{3+}}$ and absorbances satisfy Beer's law for iron in certain concentration range.
Values of $\varepsilon$ are 1309.5 and $601.5 \mathrm{~mol}^{-1} \mathrm{~cm}^{-1}$ at $625 \mathrm{~nm}$ and optimum range for accurate measurement are $1 \times 10^{-4} \approx$ $1.2 \times 10^{-3}$ and $1 \times 10^{-4} \approx 2.6 \times 10^{-3}$ for CHDP and CHEDP complex systems respectively. These ranges had obtained from Ringbom plots and Sandell's sensitivity index [15], S\% $=2.14 \times 10^{-3}$ and $4.65 \times 10^{-3}$ for $\mathrm{Fe}(\mathrm{III})$-CHDP and $\mathrm{Fe}(\mathrm{III})-$ CHEDP complex system respectively. The reproducibility of the method is checked by testing three series of solutions and the relative standard deviation is found to be less than $2 \%$.

Since iron chelates have intense colors and absorb in the region 500-600 nm, the formation constants of these species were calculated spectrophotometrically. In the region of overlapping spectrograms of the free metal ion and its complex, assuming that only 1:1 complexes are formed $\left(C_{L} / C_{M}<0.3\right)$, the following relationship holds for Fe(III)CHEDP complex system [16]: 


$$
\left[H L^{-1}\right]^{-1}=\left(1-A / A_{o}\right)\left(K_{M(H L)}^{M}-\alpha\right)-K_{M(H L)}^{M}
$$

where, A, Ao are the absorbance in the absence and presence of the ligand. $\alpha=K_{M(H L)}^{M} x\left(\varepsilon_{C} / \varepsilon_{M}\right)$ where, $\varepsilon_{C}$ and $\varepsilon_{M}$ are the molar extinctions of the complex and metal ion respectively. Plots of $\left[H L^{-1}\right]$ vs. $\left(1-A / A_{o}\right)$ gives a straight line its intercept is $-K_{M(H L)}^{M}$.

The free ligand concentration were calculated at any particular $\mathrm{pH}$ using the following equation:

$$
C_{H L^{-}}=\left[H L^{-}\right]\left(1+K_{1}^{H}\left[H^{+}\right]\right.
$$

A sample set of these calculations are shown in Fig. 7. In the region of overlapping spectrograms of Fe(III)-CHEDP complex and assuming that 1:1 complex is formed another equation is used to calculate the stability constant [17]:

$$
\log K_{M(H L)}^{M}=\log (A / \varepsilon)-\log [H L]-\log [M]
$$

where, A and $\varepsilon$ are the absorbance and molar extinction of the complex. The value of $\log K_{M(H L)}^{M}$ for Fe(III)-CHEDP complex obtained by this method is $11.31 \pm 0.16$ which is higher than the corresponding value for $\mathrm{Fe}$ (III)-CHDP complex system $\left(\log K_{M(H L)}^{M}=10.20 \pm 0.15\right)$. This difference is consistent with the structure of the two ligands. In CHEDP, the methyl group increases the basicity of the ligand, which in turns increases its stability constant.

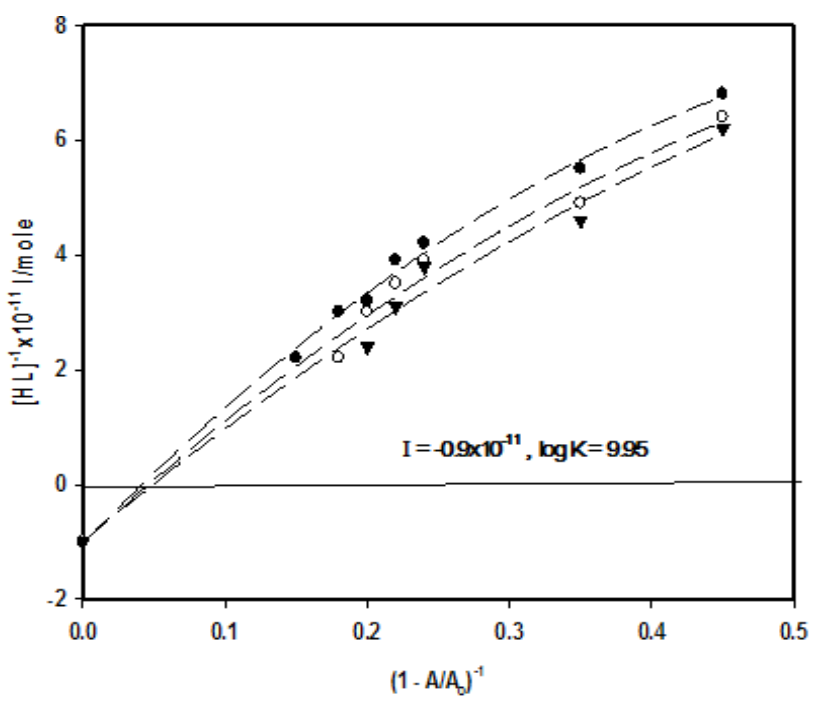

Fig. 7. Nach's plot $[H L]^{-1}$ vs. $\left(1-A / A_{0}\right)$ for Fe(III)-CHDP, system in $75 \%(v / v)$ dioxane-water ( $A$ and $A_{o}$ are absorbance in absence and present of ligand

\section{Discussion}

\begin{tabular}{|c|c|c|}
\hline & CHDP---H & CHEDP--- $\mathrm{CH}_{3}$ \\
\hline $\mathrm{E}_{\text {total }}$ & -107159.695 & -110616.484 \\
\hline $\mathrm{E}_{\text {НОмо }}$ & -9.234 & -9.1902 \\
\hline $\mathrm{E}_{\text {LUMO }}$ & -1.00386 & -0.86597 \\
\hline Heat of formation & 55.0445 & 41.3793 \\
\hline Dipole moment & 3.357 & 5.402 \\
\hline $\mathrm{Cl}-\mathrm{N}_{2}$ & 1.326 & 1.326 \\
\hline $\mathrm{N} 2-\mathrm{N} 3$ & 1.343 & 1.342 \\
\hline N3-C4 & 1.431 & 1.433 \\
\hline $\mathrm{C} 4=\mathrm{O} 33$ & 1.223 & 1.222 \\
\hline $\mathrm{C} 4-\mathrm{C} 5$ & 1.467 & 1.467 \\
\hline C5-C19 & 1.491 & 1.490 \\
\hline $\mathrm{C} 19=\mathrm{O} 20$ & 1.209 & 1.219 \\
\hline C19-C21 & 1.488 & 1.434 \\
\hline $\mathrm{C} 21-\mathrm{C} 23$ & 1.396 & 1.389 \\
\hline $\mathrm{C} 23-\mathrm{C} 24$ & 1.293 & 1.303 \\
\hline C24-H34 & 1.099 & --- \\
\hline $\mathrm{C} 24-\mathrm{C} 25$ & 1.469 & 1.479 \\
\hline $\mathrm{C} 25-\mathrm{C} 26$ & 1.408 & 1.406 \\
\hline C26-O31 & 1.366 & 1.368 \\
\hline O31-H35 & 0.9494 & 0.9492 \\
\hline
\end{tabular}

\subsection{The Ligand}

Table 7. Structural parameters of the ligands calculated using Hyper chem. 7-5 at PM3 level. 
Table 8. Some important infra-red spectral bands of CHEDP and CHDP and its complexes $\left(v\right.$ in $\left.\mathrm{cm}^{-1}\right)$.

\begin{tabular}{|c|c|c|c|c|c|}
\hline CHEDP & CHDP & CHDP-Cu(II) & CHDP-Co(II) & CHDP-Fe(III) & Assignment \\
\hline $3500 \mathrm{~b}$ & $3450 \mathrm{~b}$ & --- & ---- & --- & $\mathrm{V}_{\mathrm{OH}}$ intermolecular H-bond \\
\hline --- & --- & $3520 \mathrm{~b}$ & $3400 \mathrm{~b}$ & $3425 \mathrm{~b}$ & $\mathrm{~V}_{\mathrm{OH}-\mathrm{H}}$ \\
\hline $3200 \mathrm{~b}$ & $3200 \mathrm{~b}$ & --- & --- & --- & $\mathrm{V}_{(\mathrm{N}-\mathrm{H})}$ \\
\hline --- & 3058 & 3061 & --- & --- & $\mathrm{V}_{\mathrm{C}-\mathrm{H}}$ aromatic \\
\hline --- & 2927 & 2949 & --- & --- & Saturated $\mathrm{V}_{(\mathrm{N}-\mathrm{H})}$ \\
\hline $1680 \mathrm{~s}$ & $1680 \mathrm{~s}$ & $1710 \mathrm{~m}$ & $1630 \mathrm{~s}$ & $1654 \mathrm{~s}$ & $\mathrm{~V}_{\mathrm{C}=\mathrm{O}}$ \\
\hline $1620 \mathrm{~s}$ & $1620 \mathrm{~s}$ & $1670 \mathrm{~m}$ & $1610 \mathrm{~s}$ & $1604 \mathrm{~s}$ & $\mathrm{~V}_{\mathrm{C}=\mathrm{C}}$ \\
\hline $1510 \mathrm{~s}$ & $1490 \mathrm{~s}$ & $1500 \mathrm{~m}$ & $1550 \mathrm{~m}$ & 1538 & $\mathrm{~V}_{\mathrm{C}=\mathrm{N}}$ \\
\hline $1490 \mathrm{~s}$ & $1440 \mathrm{~m}$ & 1440 vs & $1390 \mathrm{~s}$ & $1439 \mathrm{w}$ & $V_{N=N}$ \\
\hline $1375 \mathrm{~s}$ & $1370 \mathrm{~s}$ & $1330 \mathrm{w}$ & $1350 \mathrm{~m}$ & 1384 vs & $v_{C=N_{2}}{ }^{*}$ \\
\hline $1300 \mathrm{~s}$ & $1310 \mathrm{~m}$ & $1250 \mathrm{w}$ & $1280 \mathrm{~m}$ & $1304 \mathrm{~m}$ & $\mathrm{~V}_{\mathrm{C}-\mathrm{C}}$ \\
\hline $1250 \mathrm{~s}$ & $1275 \mathrm{~s}$ & $1200 \mathrm{w}$ & $1200 \mathrm{~s}$ & $1204 \mathrm{~m}$ & $\mathrm{~V}_{\mathrm{C}-\mathrm{O}}$ \\
\hline $1150 \mathrm{~s}$ & $1190 \mathrm{mb}$ & $1180 \mathrm{w}$ & $1150 \mathrm{~m}$ & $1150 \mathrm{w}$ & $\mathrm{V}_{\mathrm{C}=\mathrm{N}}$ \\
\hline $1075 \mathrm{w}$ & $1130 \mathrm{mb}$ & $1075 \mathrm{w}$ & $1070 \mathrm{w}$ & --- & --- \\
\hline $1020 \mathrm{~m}$ & $1030 \mathrm{~s}$ & $1010 \mathrm{w}$ & 1030 & $1028 \mathrm{w}$ & --- \\
\hline $980 \mathrm{~m}$ & 960 vs & $950 \mathrm{w}$ & $920 \mathrm{w}$ & 960 & $\mathrm{~V}_{\mathrm{N}-\mathrm{N}}$ \\
\hline $940 \mathrm{~m}$ & $920 \mathrm{~m}$ & --- & --- & --- & --- \\
\hline $810 \mathrm{~m}$ & $880 \mathrm{~m}$ & $800 \mathrm{~s}$ & --- & $810 \mathrm{~m}$ & --- \\
\hline 750 vs & $750 \mathrm{~s}$ & $750 \mathrm{~s}$ & $750 \mathrm{~s}$ & 755 vs & \multirow{2}{*}{ Substituted benzene $\mathrm{v}_{\mathrm{C}-\mathrm{H}}$} \\
\hline $700 \mathrm{vs}$ & $690 \mathrm{~s}$ & $690 \mathrm{~s}$ & --- & $670 \mathrm{vs}$ & \\
\hline $640 \mathrm{~m}$ & --- & --- & --- & --- & --- \\
\hline $600 \mathrm{~m}$ & --- & $650 \mathrm{w}$ & $650 \mathrm{w}$ & $604 \mathrm{~m}$ & $\Phi_{\mathrm{C}-\mathrm{C}}$ aromatic \\
\hline --- & --- & $580 \mathrm{w}$ & $600 \mathrm{w}$ & 551 & \multirow{2}{*}{$\mathrm{V}_{\mathrm{M}-\mathrm{O}} ; \mathrm{V}_{\mathrm{M}-\mathrm{N}}$} \\
\hline--- & --- & $540 \mathrm{w}$ & $470 \mathrm{w}$ & 446 & \\
\hline
\end{tabular}

$\mathrm{s}=$ strong $; \mathrm{m}=$ medium $; \mathrm{w}=$ weak $; \mathrm{b}=$ broad $; \mathrm{v}=$ very

frequency in $\mathrm{cm}-1$

*the atoms are numbered in the structures

The analytical and spectral data prove that each ligand is a mixture of two tautomeric isomers is shown in the following<smiles>[R]C1=NN([2H])N[C@H](C(=O)C2C(=O)NN=C([R])C2c2ccccc2)c2ccccc2O1</smiles>

(1)<smiles>[R]C1=NN=C(C(O)=N[TlH])C(c2ccccc2)C1=O</smiles>

(2)

$$
[R=-H \rightarrow C H D P],\left[R=\mathrm{CH}_{3} \rightarrow C H E D P\right] .
$$

Thus the IR-spectrum of the ligands CHDP and CHEDP could be associated with both tautomeric isomers 1 and 2 . The $v_{\mathrm{N}-\mathrm{H}}, v_{\mathrm{C}=\mathrm{N}}$ and $v_{\mathrm{C}=\mathrm{O}}$ of tautomeric isomer 1 are detected at 3200,1680 and $1620 \mathrm{~cm}^{-1}$ respectively (Table 8). The phenolic $-\mathrm{OH}$ is observed at 3450 and $3500 \mathrm{~cm}^{-1}$ as broad bands for CHDP and CHEDP respectively. The broadness of such band could be related to hydrogen bonding with $-\mathrm{C}=\mathrm{N}$ group. Evidence for tautomeric structure 2 is derived from IR bands related to $v_{\mathrm{N}-\mathrm{N}}$ and $v_{\mathrm{C}-\mathrm{O}}$ which appeared at 980-960 and $1275-1280 \mathrm{~cm}^{-1}$ respectively.

The ${ }^{1} \mathrm{H}-\mathrm{NMR}$ spectrum (DMSO-d6) of CHEDP shows at $\delta$ $2.2\left(\mathrm{~s}, 3 \mathrm{H}, \mathrm{CH}_{3}\right) ; 6.5-7.4(\mathrm{~m}, 15 \mathrm{H}, \mathrm{Ar}-\mathrm{H}$ phenolic $\mathrm{OH}) .10 .7$

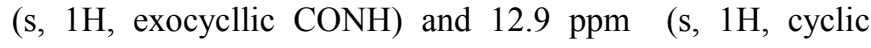
$\mathrm{CONH}$ ). The structure of CHEDP compound was further confirmed by the mass spectrum which exhibited peaks at $\mathrm{m} / \mathrm{e} \quad 424 \quad(78.34 \%) \quad\left[\mathrm{M}^{+} \mathrm{C}_{25} \mathrm{H}_{20} \mathrm{~N}_{4} \mathrm{O}_{3}\right] ; \quad 409 \quad(34.28 \%)$ $\left[\mathrm{C}_{24} \mathrm{H}_{17} \mathrm{~N}_{4} \mathrm{O}_{3}\right] ; 378$ (13.24\%) $\left[\mathrm{C}_{25} \mathrm{H}_{18} \mathrm{~N}_{2} \mathrm{O}_{2}\right] ; 290(40.72 \%)$ $\left[\mathrm{C}_{18} \mathrm{H}_{14} \mathrm{~N}_{2} \mathrm{O}_{2}\right] ; 275$ (100\%) $\left[\mathrm{C}_{17} \mathrm{H}_{11} \mathrm{~N}_{2} \mathrm{O}_{2}\right] ; 247$ (83.17\%) $\left[\mathrm{C}_{16} \mathrm{H}_{11} \mathrm{~N}_{2} \mathrm{O}_{2}\right] ; 219(25 \%)\left[\mathrm{C}_{16} \mathrm{H}_{11} \mathrm{O}\right]$ and $203(13.12 \%)$ $\left[\mathrm{C}_{16} \mathrm{H}_{11}\right]$. The base peak at $\mathrm{m} / \mathrm{e} 275(100 \%)$ is formed due to loss of $\left(\mathrm{C}_{17} \mathrm{H}_{12} \mathrm{~N}_{2} \mathrm{O}_{2}\right)$ from the parent ion peak of CHEDP, and the base peak at $\mathrm{m} / \mathrm{e} 122(100 \%)$ is formed due to loss of $\left(\mathrm{C}_{7} \mathrm{H}_{8} \mathrm{NO}\right)$ from the parent peak for CHDP.

Furthermore, the proposed structure of the ligands were optimized and structure parameters were evaluated by means of semi-empirical molecular obtained calculations of $\mathrm{MP}_{3}$ level provided by hyper Chem. release 7.5. The calculated structural parameters data are summarized in Table 7. The heat of formation $\left(\Delta \mathrm{H}_{\mathrm{f}}\right)$, dipole moment, HOMO and LUMO entropies and $\Delta \mathrm{E}_{\mathrm{gap}}=\left(\Delta \mathrm{E}_{\mathrm{HOMO}}-\Delta \mathrm{E}_{\mathrm{LOMO}}\right)$ as well as bond 
length. Analysis of the data indicates that the calculated heat of formation $\left(\Delta \mathrm{H}_{\mathrm{f}}\right)$ as well as $\Delta \mathrm{E}_{\text {gap }}$ values of the present ligand, suggest that the more favorable toutomeric forms are shown in the following diagram

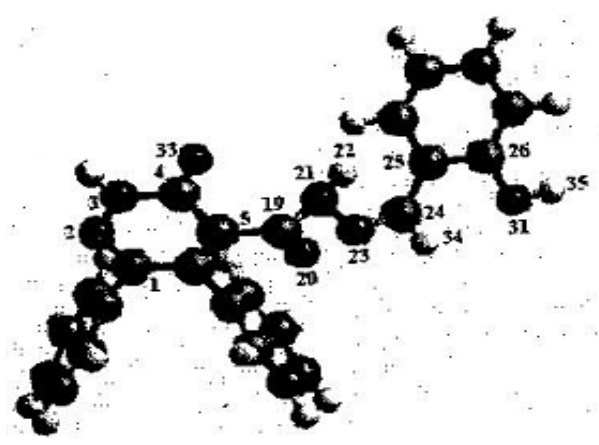

CHDP....H

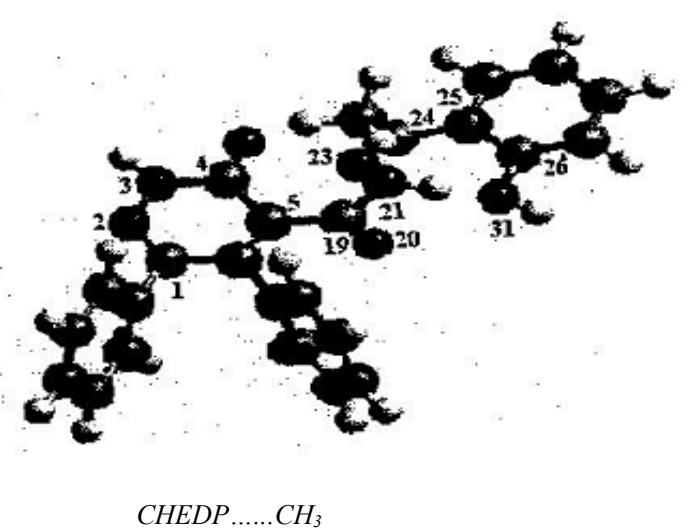

\subsection{Solid Complexes}

\subsubsection{Conductivity and Magnetic Properties}

The metal complexes, which were isolated in the present study, are presented in Table 1 together with some of their properties. The deprotonation of hydrazo and phenolic protons occurs in 1:1 $\mathrm{Fe}(\mathrm{III})-\mathrm{CHDP}$ while in cases of $\mathrm{Cu}(\mathrm{II})$ CHDP and Co(II)-CHDP complexes only the phenolic group is deprotonated. The molar conductance values of $10^{-3} \mathrm{M}$ complex solution in DMF are 15,67.00 and 75.20 MS/cm for copper, cobalt and iron complexes respectively. This indicates that 1:1 electrolyte for cobalt and iron complexes, while nonionic nature for copper complex.

The magnetic moments $\left(\mu_{\text {eff }}\right)$ of iron (III) and cobalt (II) complexes are 5.67 and 4.41 , which are normal and suggest octahedral geometry for them. The magnetic moment of copper (II) complexes reported here is in the range $\approx 1.8 \mathrm{~B}$.M. accepted for $\mathrm{Cu}(\mathrm{II})$ complexes [18] (one unpaired electron).

\subsubsection{IR Spectra of the Complexes}

The infrared spectra of these solids show a systematic shift of $v_{\mathrm{C}=\mathrm{C}}, v_{\mathrm{C}=\mathrm{N}}$ and $v_{\mathrm{C}=\mathrm{O}}$ bands to lower frequency with the simultaneous disappearance of $v_{\mathrm{N}-\mathrm{H}}$ and $v_{\mathrm{O}-\mathrm{H}}$ bands. The $v_{\mathrm{O}-\mathrm{H}}$ band in the free ligand is not observed but is replaced by a broader band at $3400-3520 \mathrm{~cm}^{-1}$ in the spectrum of the complex due to $v_{\mathrm{O}-\mathrm{H}}$ of the coordinated water molecules. The participation of phenolic oxygen and azo-methane or N-H

nitrogen are substantiated from the appearance of new bands at 551-580 and $340-470 \mathrm{~cm}^{-1}$ on the spectra of the solid complexes assigned to $v_{\mathrm{M}-\mathrm{O}}$ and $v_{\mathrm{M}-\mathrm{N}}$ respectively.

\subsubsection{Thermal Analysis (TG-DSC)}

The results of TG-DSC studies of CHDP ligand and its complexes $\mathrm{Cu}(\mathrm{II})-, \quad \mathrm{Co}(\mathrm{II})-$ and $\mathrm{Fe}(\mathrm{III})-\mathrm{CHDP}$ are summarized in Table (9) at ambient temperature up to $800^{\circ} \mathrm{C}$, the rate is $20^{\circ} \mathrm{C}$ per minute. The composition of intermediates proposed were the best fit of the observed weight loss. The TG curve of the free ligand as shows a very rapid and big mass loss (second step) in the range $198.86-437.62^{\circ} \mathrm{C}$ corresponding to the liberation of organic moiety $\mathrm{C}_{17} \mathrm{H}_{11} \mathrm{~N}_{2} \mathrm{O}_{2}$ [found 63.74; calc. 64.25]. The exothermic peak at $400^{\circ} \mathrm{C}$ originates from the combustion of carbon from the organic part. The first decomposition stage starts at $44.41^{\circ} \mathrm{C}$ and continues until $198.86^{\circ} \mathrm{C}$, corresponding to the degradation of $2 \mathrm{H}_{2} \mathrm{O}$ molecules (one crystalline $\mathrm{H}_{2} \mathrm{O}$ and the other from the ligand) constituting about 8.17 of the total weight loss (8.41 calc.)The third step show the decomposition of the remaining part of the molecule $\mathrm{C}_{7} \mathrm{H}_{5} \mathrm{~N}_{2}$ at $438.99-798.80^{\circ} \mathrm{C}$ temperature range (found: 27.65; calc. 27.34). DSC analysis was performed in order to obtain quantitative results for thermal effects accompanying various processes occurring during heating.

Table 9. DTA and DSC data for CHDP complexes

\begin{tabular}{|c|c|c|c|c|c|c|c|c|}
\hline \multirow{2}{*}{ Compound } & \multirow{2}{*}{ stage } & \multirow{2}{*}{ Temperature range ${ }^{\circ} \mathrm{C}$} & \multicolumn{2}{|c|}{ Weight \% } & \multicolumn{2}{|c|}{ DSC peak } & \multirow{2}{*}{$\Delta \mathbf{H} \mathbf{J} / \mathbf{g}$} & \multirow{2}{*}{ Product } \\
\hline & & & Found & Calc. & Endo & Exo & & \\
\hline \multirow{6}{*}{$\begin{array}{l}{\left[\mathrm{Cu}\left(\mathrm{C}_{24} \mathrm{H}_{17} \mathrm{~N}_{4} \mathrm{O}_{3}\right)\left(\mathrm{H}_{2} \mathrm{O}\right)_{3}\left(\mathrm{NO}_{3}\right)\right] \mathrm{H}_{2} \mathrm{O}} \\
606.55\end{array}$} & 1 & $42.6-183.1$ & 3.28 & 2.97 & & -120 & -72.55 & $\mathrm{H}_{2} \mathrm{O}$ \\
\hline & 2 & $184.8-377.6$ & 16.25 & 16.49 & 323 & & 55.11 & $\mathrm{NO}_{2} ; 3 \mathrm{H}_{2} \mathrm{O}$ \\
\hline & 3 & $377.6-413.7$ & 22.04 & 22.09 & 354 & & 89.12 & $\mathrm{C}_{7} \mathrm{H}_{6} \mathrm{ON}_{2}$ \\
\hline & 4 & $413.7-498.9$ & 22.56 & 21.76 & 417 & & & $\mathrm{C}_{11} \mathrm{H}_{2} \mathrm{O}$ \\
\hline & 5 & $498.9-565.2$ & 22.38 & 23.25 & & -600 & & $\mathrm{C}_{6} \mathrm{H}_{9} \mathrm{~N}_{2} \mathrm{O}_{2}$ \\
\hline & & Above 565.2 & 13.43 & 13.11 & & & & $\mathrm{CuO}$ \\
\hline \multirow{6}{*}{$\begin{array}{l}{\left[\mathrm{Co}\left(\mathrm{C}_{24} \mathrm{H}_{17} \mathrm{~N}_{4} \mathrm{O}_{3}\right)\left(\mathrm{H}_{2} \mathrm{O}\right)_{3}\right] \mathrm{NO}_{3} \cdot \mathrm{H}_{2} \mathrm{O}} \\
601.9\end{array}$} & 2 & $102.0-143.5$ & 3.20 & 2.99 & 147 & & -4.26 & $\mathrm{H}_{2} \mathrm{O}$ \\
\hline & 3 & $143.5-272.9$ & 5.74 & 5.98 & 401 & & -87.37 & $2 \mathrm{H}_{2} \mathrm{O}$ \\
\hline & 4 & $272.9-443.0$ & 19.10 & 19.77 & 415 & & -98.23 & $\mathrm{C}_{7} \mathrm{H}_{5} \mathrm{NO}$ \\
\hline & 5 & $443.0-604.5$ & 36.35 & 36.22 & 466 & & -101.42 & $\mathrm{C}_{13} \mathrm{H}_{2} \mathrm{~N}_{2} \mathrm{O}_{2}$ \\
\hline & 6 & $604.5-671.0$ & 4.40 & 4.65 & 600 & & -73.16 & $\mathrm{CO}$ \\
\hline & & Above 671 & 28.06 & 29.72 & & & & $\mathrm{CoO}$ \\
\hline
\end{tabular}




\begin{tabular}{|c|c|c|c|c|c|c|c|c|}
\hline \multirow{2}{*}{ Compound } & \multirow{2}{*}{ stage } & \multirow{2}{*}{ Temperature range ${ }^{\circ} \mathrm{C}$} & \multicolumn{2}{|c|}{ Weight \% } & \multicolumn{2}{|c|}{ DSC peak } & \multirow{2}{*}{$\Delta \mathbf{H ~ J / g}$} & \multirow{2}{*}{ Product } \\
\hline & & & Found & Calc. & Endo & Exo & & \\
\hline \multirow{5}{*}{$\begin{array}{l}{\left[\mathrm{Fe}\left(\mathrm{C}_{24} \mathrm{H}_{16} \mathrm{~N}_{4} \mathrm{O}_{3}\right)\left(\mathrm{H}_{2} \mathrm{O}\right)_{3}\right] \mathrm{NO}_{3} .2 \mathrm{H}_{2} \mathrm{O}} \\
615.85\end{array}$} & 1 & $34.3-152.0$ & 10.29 & 10.39 & \multirow{5}{*}{$\begin{array}{l}180.2 \\
333.4 \\
420.2\end{array}$} & \multirow[t]{5}{*}{-83.2} & -54.47 & $\mathrm{NO}_{2} ; \mathrm{H}_{2} \mathrm{O}$ \\
\hline & 2 & $152.0-257.6$ & 11.38 & 11.69 & & & -15.11 & $4 \mathrm{H}_{2} \mathrm{O}$ \\
\hline & 3 & $257.6-401.0$ & 19.80 & 19.97 & & & -57.11 & $\mathrm{C}_{6} \mathrm{H}_{5} \mathrm{NO}_{2}$ \\
\hline & 4 & $401.0-743.0$ & 41.68 & 41.73 & & & & $\mathrm{C}_{17} \mathrm{H}_{11} \mathrm{~N}_{3}$ \\
\hline & & Above 743.0 & 16.85 & 16.21 & & & & $\mathrm{FeO} ; \mathrm{CO}$ \\
\hline
\end{tabular}

The measurements were carried out at nearly the same rate as used for TG investigation. The composition of $\mathrm{TG}$ and DSC analysis is a very useful tool in the investigation and characterization of thermal behavior of organic compound. The values of thermodynamic quantities with particular TG and DSC curves for $\left[\mathrm{Fe}\left(\mathrm{C}_{24} \mathrm{H}_{16} \mathrm{~N}_{4} \mathrm{O}_{3}\right)\left(\mathrm{H}_{2} \mathrm{O}\right)_{3}\right] \mathrm{NO}_{3} \cdot 2 \mathrm{H}_{2} \mathrm{O}$, (Table 9). The transition enthalpy values give information about the dimensions of thermal effects, being a sum of all processes that taking place in the particular temperature range. The thermal parameters of conversion of 1 and 2 steps are not similar $\left(\mathrm{H}_{1}=-54.36 \mathrm{~J} / \mathrm{g}\right.$ and $\left.\mathrm{H}_{2}=-15.11 \mathrm{~J} / \mathrm{g}\right)$ because they are connected with loss of $\mathrm{H}_{2} \mathrm{O}$ and $\mathrm{NO}_{2}$ for the first step while the second step four of coordination water molecules are lost. The transition enthalpy of steps (3) is high $\left(\mathrm{H}_{3}=-57.11 \mathrm{~J} / \mathrm{g}\right)$, which is due to release of $\mathrm{C}_{6} \mathrm{H}_{5} \mathrm{NO}_{2}$ moiety.

In the thermo gram of the complex $\left[\mathrm{Fe}\left(\mathrm{C}_{24} \mathrm{H}_{16} \mathrm{~N}_{4} \mathrm{O}_{3}\right)\left(\mathrm{H}_{2} \mathrm{O}\right)_{3}\right] \mathrm{NO}_{3} \cdot 2 \mathrm{H}_{2} \mathrm{O}$, there are four steps of weight losses from room temperature to $743.0^{\circ} \mathrm{C}$. The complex lost 10.29 of its weight at $34.34-151.99^{\circ} \mathrm{C}$ due to the liberation of $\mathrm{NO}_{2}$ and $\mathrm{H}_{2} \mathrm{O}$ molecules (calc. 10.39). In the second step 4 molecules of coordinated water are lost (found 11.38 and calc. 11.69). The third step occurred at 259.6$401.0^{\circ} \mathrm{C}$ range is due to the loss of $\mathrm{C}_{6} \mathrm{H}_{5} \mathrm{NO}_{2}$ moiety from the organic part of ligand molecule (found 19.80, calc. 19.97). The remaining weight loss 41.68 is for organic matter $\mathrm{C}_{17} \mathrm{H}_{11} \mathrm{~N}_{3}$ obtained at $401.01-742.99^{\circ} \mathrm{C}$ range (calc. 41.73 ). The remaining weight loss above $742.99^{\circ} \mathrm{C}$ is corresponding to the oxide molecules $\mathrm{FeO}$ and $\mathrm{CO}$ (found 16.85, calc. 16.21).

The TG curve of copper complex shows about five steps, the first one gives a weight loss about $3.28 \%$ (calc. 2.97) due to one mole of crystalline water and is characterized by an exothermic peak in the DSC curve at $120^{\circ} \mathrm{C}$. The second step is due to loss of $\mathrm{NO}_{2}$ and $3 \mathrm{H}_{2} \mathrm{O}$ (found 16.25 , calc. 16.49) and show an endothermic peak in DSC curve at $323^{\circ} \mathrm{C}$. The other remaining steps were due to loss of $\mathrm{C}_{7} \mathrm{H}_{6} \mathrm{ON}_{2}, \mathrm{C}_{11} \mathrm{H}_{2} \mathrm{O}$ and $\mathrm{C}_{6} \mathrm{H}_{9} \mathrm{~N}_{2} \mathrm{O}_{2}$ organic moieties. These steps are characterized by two endothermic and one exothermic peak in DSC curve. $\mathrm{CuO}$ is appeared as a final product above $565^{\circ} \mathrm{C}$, (found 13.43 , calc. 13.11 ).

In case of cobalt complex, the decomposition process was completed and cobalt oxide $(\mathrm{CoO})$ is formed above $600^{\circ} \mathrm{C}$. The first three steps are due to the loss of crystalline and coordinated water molecules.

\subsubsection{Mass Spectra}

The molecular formulas of the above complexes were substantiated through mass spectra. The iron(III) complex $\left[\mathrm{Fe}\left(\mathrm{C}_{24} \mathrm{H}_{16} \mathrm{~N}_{4} \mathrm{O}_{3}\right)\left(\mathrm{H}_{2} \mathrm{O}\right)_{3}\right] \mathrm{NO}_{3} .2 \mathrm{H}_{2} \mathrm{O}$ (F.w., 615.85) show the highest mass peak at 603, which agrees with the formula weight of the complex $\left[\mathrm{Fe}\left(\mathrm{C}_{24} \mathrm{H}_{16} \mathrm{~N}_{4} \mathrm{O}_{3}\right)\left(\mathrm{H}_{2} \mathrm{O}\right)_{3}\right] \mathrm{NO}_{3} \cdot 1 \frac{1}{4} \mathrm{H}_{2} \mathrm{O}$ (F.w., 603). The fragmentation patterns of the iron complex shows a fragment due to hydrated ligand molecule $\left(\mathrm{C}_{24} \mathrm{H}_{17} \mathrm{~N}_{4} \mathrm{O}_{3}\right) \cdot 3 / 4 \mathrm{H}_{2} \mathrm{O}$ at 423 .

For cobalt complex $\left[\mathrm{Co}\left(\mathrm{C}_{24} \mathrm{H}_{17} \mathrm{~N}_{4} \mathrm{O}_{3}\right)\left(\mathrm{H}_{2} \mathrm{O}\right)_{3}\right] \mathrm{NO}_{3} \cdot \mathrm{H}_{2} \mathrm{O}$ of F.w. 601.9 the highest mass peak is at 602 , which agrees with the formula weight of cobalt complex. The fragmentation patterns of the complex show fragment at 439 due the ligand molecule with $13 / 4$ water molecules $\left(\mathrm{C}_{24} \mathrm{H}_{17} \mathrm{~N}_{4} \mathrm{O}_{3}\right) 13 / 4 \cdot \mathrm{H}_{2} \mathrm{O}$.

The mass spectrum of the copper complex $\left[\mathrm{Cu}\left(\mathrm{C}_{24} \mathrm{H}_{17} \mathrm{~N}_{4} \mathrm{O}_{3}\right)\left(\mathrm{H}_{2} \mathrm{O}\right)_{3}\left(\mathrm{NO}_{3}\right] \mathrm{H}_{2} \mathrm{O}\right.$ shows a peak at 603 which in agreement with molecular formula of the complex (606.55). From the above discussion, the structure of the three investigated complexes is shown in the following scheme:<smiles></smiles>

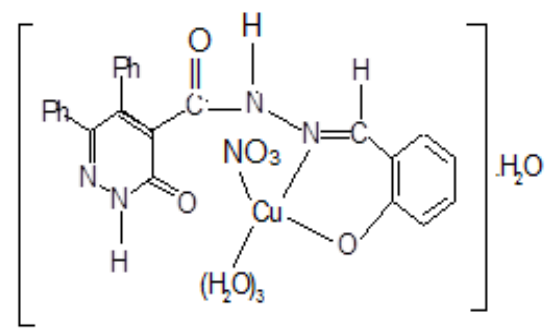<smiles>Cc1n[nH]c(=O)c(-c2ccccc2)c1C(=O)NN1C(=O)c2ccccc2OC1(O)O</smiles>

\subsection{Complexes in Solution State}

The values of acid dissociation constants $K_{1}^{H}$ and $K_{2}^{H}$ (phenolic -OH) and (hydrazo - NH) of CHEDP and CHDP ligands are not similar Table (2). This would indicate that the total inductive and hyper-conjugation effects of methyl group in CHEDP on the reagent basicity $\left(\sum K_{1}^{H}+K_{2}^{H}\right)$ are mainly dependent on the presence of such methyl group. The 
absence of this group in CHDP ligand could be account for the lower basicity of the ligand compared to CHEDP under similar conditions.<smiles>[R]c1c([Y](N)NC(=O)c2[nH]nc(-c3ccccc3)c2-c2ccccc2)oc2ccccc12</smiles>

$R=H$ in $C H D P ; R=\mathrm{CH}_{3}$ in $C H E D P$

All thermodynamic parameters of the dissociation process of the ligands are given in Table $(2,3)$. These values reveal that:

- The stepwise $p K^{H}$ values decreasing with increasing temperature, demonstrating that its acidity increasing with increasing temperature.

- $\Delta \mathrm{H}$ is positive indicating that dissociation is accompanied by absorption of heat and the process is endothermic.

- $\Delta \mathrm{G}$ is positive indicating that the dissociation process is not spontaneous.

- $\Delta \mathrm{S}$ is negative due to increased order as a result of salvation process.

The values of $\Delta \mathrm{G}$ of protic and non-protic complexes formed between CHEDP and divalent metal ions are listed in Table (4). The relationship between $\Delta \mathrm{G}$ for $\mathrm{M}(\mathrm{HL}), \mathrm{M}(\mathrm{HL})_{2}$, $\mathrm{ML}(\mathrm{HL})$ and $\mathrm{ML}_{2}$ complexes and second ionization potential of different metals is plotted in Fig. 8. The linear relation indicates that the two primary factors affecting the stability of the complexes formed between these ions and CHEDP are ionic radii and atomic number.

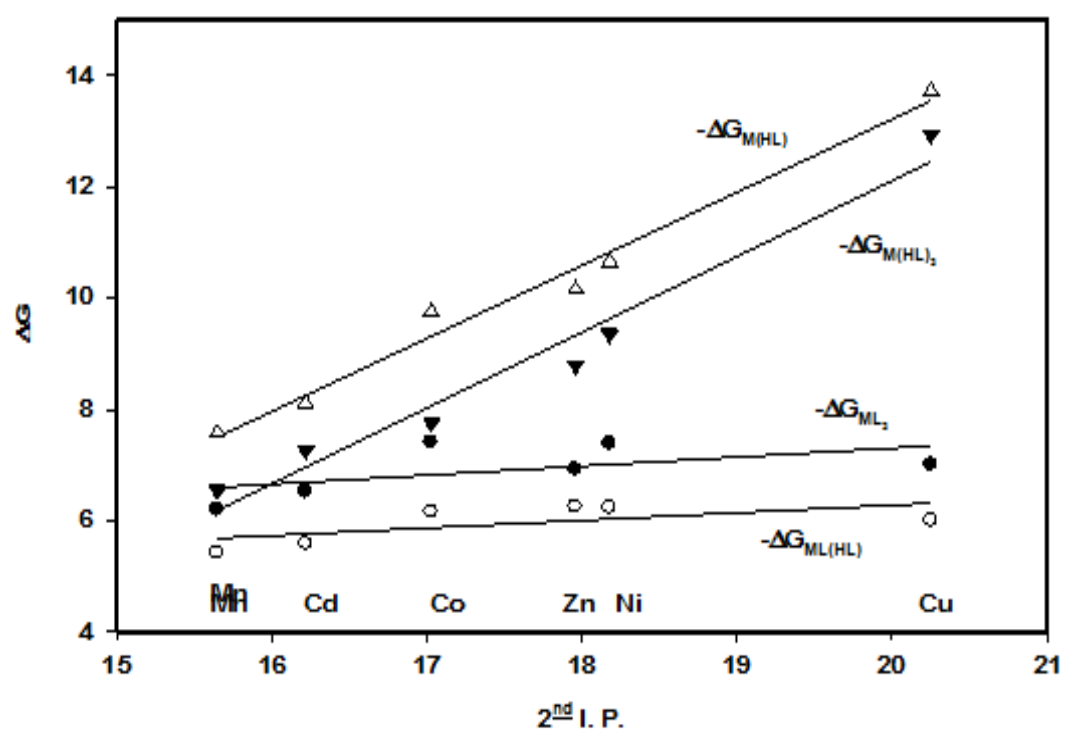

Fig 8. Graphic relation between second ionization potential and free energy for some $\mathrm{M}^{+2}$-CHEDP chelates

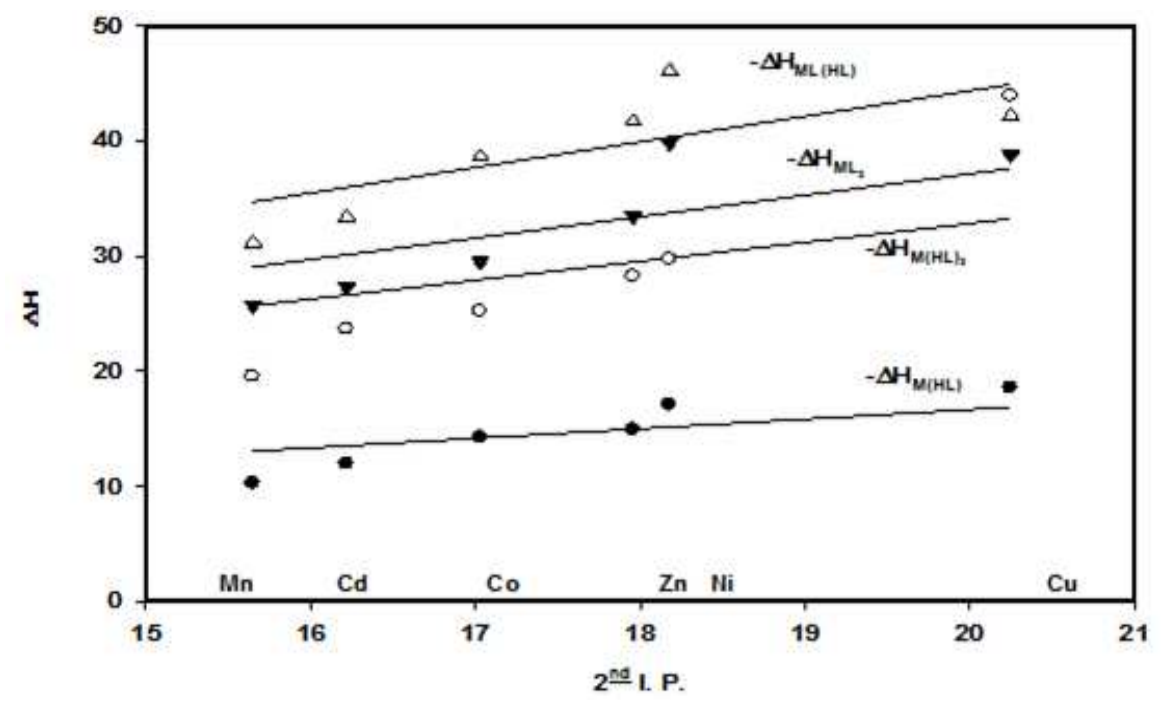

Fig. 9. Graphic relation between second ionization potential and enthalpy change for some $M^{+2}$-CHEDP chelates

The wide spread success of the relation between $\Delta \mathrm{H}$ for the protic and non-protic complex species and second 
ionization potentials of the metal ions shown in Fig. 9, indicates that the entropy of a series of chelation reaction with a given reagent will either be roughly constant or will vary regularly. This relationship is used because $\Delta \mathrm{H}$ express bond strength, also the second ionization potential may be taken as a rough estimation of the average electron attracting power of a divalent metal ion. It will also be a measure of the attracting power of a divalent metal ion for a source of electrons such as that formed in the chelate ligand groups. Hence, it is more nearly related to bond energy and $\Delta \mathrm{H}$ of chelation than $\Delta \mathrm{G}$ as measured by $\log$ of chelate formation constants. It should also be noted that since in many cases $\Delta \mathrm{H}$ are accompanied by opposing charge in $\Delta \mathrm{S} . \Delta \mathrm{H}$ should be a more sensitive index of bond strength than $\Delta \mathrm{G}$. Fig. 9, shows a plot of second ionization potential of the gaseous metal atom against $\Delta \mathrm{H}$ of chelation. As can be seen the relationship is satisfactory.

CHEDP forms MHL (protic) chelates as evidenced both by the titration curves and isolation of solid complexes. Probable arrangement of the order groups is shown in structure (III) with the $\mathrm{M}$ replacing $\mathrm{H}_{1}$. As more base added, the $\mathrm{pH}$ becomes sufficiently high to assist in the dissociation of the second protons $\left(-\mathrm{H}_{2}\right)$. The basicity of this proton is not as strong as in the free ligands and influenced by the presence of metal ion in the following order: $\mathrm{Ni}<\mathrm{Co} \approx \mathrm{Cu}<$ $\mathrm{Zn}<\mathrm{Mn}<\mathrm{Cd}$, which is in a revised order of stabilities of the normal chelates.

\section{References}

[1] G. De Munno, G. Denti and P. Dapporte, Inorg. Chim. Acta, 74, (1983) 199-203.

[2] B. A. El-Shetary, M. S. Abdel-Moez and S. S. Sleem, Thermo Chemica Acta, 113, (1987) 21-29.
[3] A. A. T. Ramadan, M. H. Seada and E. N. Rizkalla, Talanta, 30, (1983) 245- 250.

[4] E. N. Rizkalla, A. A. T. Ramadan and M. H. Seada, Polyhedron, 2, (1983) 1155-1164.

[5] A. A. T. Ramadan, M. H. Seada and E. N. Rizkalla, Monatshefte fur Chemie, 116, (1985) 461- 477.

[6] F. A. Snavely, W. C. Fernelius and B. P. Block, J. Am. Chem. Soc., 79, (1957) 1028- 1030.

[7] Snavely, F. A., Krecker, B. D. and Clark, C. G.; J. Am. Chem. Soc. 81, (1959) 2337- 2338.

[8] M. H. Seada, M. M. Fawezy, H. Jahine, M. Abdel-Magid and R. R. Saad, J. Chin. Chem. Soc. 36 (1989) 241- 245.

[9] H. M. Irving and U. S. Mohanant, J. Inorg. Nucl. Chem. 30, (1968) 1215- 1220.

[10] A. Albert and E. P. Serjeant, "Ionization Constants of Acids and Bases" Chopman and Hall, Edinburgh, 1971.

[11] D. F. Goldberg, J. Chem. Educ. 40, (963) 341- 347.

[12] R. M. Sitverstein, G. O. Bassler and T. C. Morrill, "Spectrophotometric Identification of Organic Compounds" $4^{\text {th }}$ Ed., Willey, New York, 1981.

[13] J. S. Colman, L. P. Varga and S. H. Martin, Inorg. Chem. 9, (1970) 1015- 1020.

[14] F. J. Rossotti and H. Rossotti, "Determination of Stability Constants", Mc Graw, Hill, New York, 1961.

[15] A. Bubko and A. Pilipenko, "Photometric Analysis" MIR Pub., Moscow, 227, (1971).

[16] C. P. Nach, Phys. Chem. Soc., 64, (1960) 950- 958.

[17] H. E. Bent and G. L. French, J. Am. Chem. Soc., 63, (1941) 568- 576.

[18] F. A. Cotton, and G. Wilkenson, "Advanced Inorganic Chemistry" $3^{\text {th }}$ ed. Interscience, New York, 1972. 